УДК 336.74

\title{
АЛЬТЕРНАТИВНІ ВАЛЮТИ ЯК ДРАЙВЕР ГРОШОВОГО ПЛЮРАЛІЗМУ
}

\author{
ПАНТЕЛСЄВА Наталія Миколаївна \\ доктор економічних наук, професор \\ Черкаський інститут Університету банківської справи \\ ORCID ID: https://orcid.org/0000-0001-6457-6912 \\ e-mail:nnpanteleeva2017@gmail.com
}

\section{БОНДАР Жанна Богданівна}

здобувач вищої освіти,

Черкаський інститут Університету банківської справи

e-mail: zhannabondar13@gmail.com

Анотація. В статті обгрунтовано значення альтернативних валют у формуванні грошового плюралізму, наявність сильноі корелячії між їх виникненням $i$ розвитком та економічними кризами, науковотехнічним прогресом і глобальними трендами. Доведено зміну парадигми сприйняття альтернативних валют - від прямого протистояння та конкурениії до співіснування у доповненні до традииійної грошової системи. Розкрито сутність альтернативних валют, їх функиії та топологію, виявлено характеристичні особливості окремих їх видів, зокрема, валют, щзо засновані на часу, енерговалют, ичифрових валют, валют громад, на основі компаративного аналізу, визначено їх сильні $і$ слабкі сторони, а також можливості $i$ загрози для їх прийняття і поширення.

Ключові слова: грошова система, кредитно-банківська система, грошовий плюралізм, альтернативні валюти, криптовалюта.

Постановка проблеми. Сучасна кредитно-банківська система базується на непорушних положеннях грошової і валютної системи і авторитеті грошей, як засобу товарно-грошових і
Аннотация. $B$ cmaтье обосновано значение альтернативньх валют в формировании денежного плюрализма, наличие сильной корреляции между их возникновением и развитием и экономическими кризисами, научно-техническим прогрессом и глобальными трендами. Доказано смену парадигмы восприятия альтернативных валют - от прямого противостояния и конкуренции к сосущеествованию в дополнении к традищионной денежной системы. Раскрыта сущзность альтернативных валют, их функции и топология, выявлено характерные особенности отдельных их видов, в частности, валют, основанных на времени, енерговалют, ииффровых валют, валют общчин, на основе сравнительного анализа, определены их сильные и слабые стороны, а также возможности и угрозы для их принятия и распространения.

Ключевые слова: денежная система, кредитно-банковская система, денежный плюрализм, альтернативные валюты, криптовалюта.

кредитних відносин, де гроші $\epsilon$ об'єктом обміну, а за інших обставин засобом обігу і засобу накопичення, а також валютою при здійсненні валютних відносин. Проте із збільшенням 
частоти глобальних викликів, а саме зростанням економічної і соціальної нерівності, тіньової і спекулятивної економіки, підвищенням невизначеності і кризових явищ 3 важкими наслідками для національних та глобальної економіки в цілому, пришвидшуються процеси еволюційного розвитку кредитно-банківської системи.

Виникнення феномену альтернативних валют та їх поширення в умовах грошового плюралізму підтверджує, що останній варто розглядати 3 позиції субсидіарності, адже альтернативні валюти фактично намагаються компенсувати недосконалість грошово-кредитної політики і провали ринку, задовольнити соціальні потреби, адже їх антициклічний характер тривалий час проявлявся переважно під час економічних криз. Сьогодні процес цифрового перезавантаження всіх без винятку традиційних систем потребує більш комплексного дослідження сутності і потенціального впливу альтернативних валют на грошову і кредитно-банківську системи.

Аналіз останніх досліджень і публікацій. Питанням дослідження сутності альтернативних валют, особливостей їх функціонування та визначення проблемних аспектів приділяли увагу зарубіжні і вітчизняні вчені та експерти, зокрема: С. Альварес, Р. Абдуллаев, С. Афоніна, С. Балацкій, Г. Білоглазова, Б. Бернанке, А. Генкін, Ч. Гудхард, В. Достов, Б. Івасів, Г. Карчева, В. Катасонов, К. Кемпбелл, М. Кінг, В. Корнеєв, В. Кравець, Л. Красавіна, М. Крюгер, Д. Кочергін, А. Маклауд, І. Лютий, О. Махаєва, Дж. Мілль, Р. Міллер, В. Міщенко, С. Міщенко, А. Мороз, С. Науменкова, I. Нікішкіна, Н. Пантєлєєва, В. Пономарьов, Л. Примостка, М. Ріверо,
М. Савлук,

Р. Сайфуллаева, Ш. Сайфуллаев, І. Сисоєв, П. Сенищ, Р. Селджін, К. Скінер, Т. Смовженко, I. Сухій, В. Усоскін, Т. Утолін, І. Фішер, М. Фрідмен, Ю. Хватов, С. Хант, В. Хаустова, Н. Чоу, Д. Чаум, Я. Юдонг, О. Яковлев та ін.

Метою статті $\epsilon$ систематизація теоретико-методичних засад, передумов виникнення та поширення альтернативних валют, визначення їх характеристичних особливостей та видів, а також слабких і сильних сторін, загроз і можливостей.

Результати дослідження. Посилення диспропорцій у розвитку світової валютної системи внаслідок кризових явищ на макро- і мікрорівні світової і національної економік, інфляція, девальвація національних валют і дестабілізація в розвитку грошових і валютних систем зумовили втрату фінансової стабільності та екологічної, економічної та соціальної стійкості. Ці процеси та їх негативні наслідки постійно активізують пошук інноваційних форм альтернативних валют, що здатні радикально трансформувати сферу грошових і валютних відносин, врахувати виклики глобалізованого світу задля забезпечення фінансової стабільності.

Поряд 3 цим, важливою передумовою для виникнення альтернативних валют та їх поширення $\epsilon$ науковотехнічний прогрес і глобальні тренди, а саме цифровізація, що на основі інформаційно-комунікаційних технологій, інтернету та мереж високошвидкісної передачі інформації сприяє прискоренню здійснення фінансових операцій і підвищує швидкість обігу капіталу. Такий ii потужний потенціал стає основою для трансфор- 
маційних процесів грошової і валютної системи.

Як наслідок, наприкінці XX століття 3'явились електронні гроші, платіжні картки і безготівкові розрахунки. Зокрема, електронні гроші не вплинули на масу грошей в обігу і не похитнули право центральних банків на монополію емісії грошей i сеньйораж. На початку XXI століття відкриті стандарти для платіжних систем 3 узгодженими міжнародними принципами конфіденційності і соціальної відповідальності, мобільний та інтернет-банкінг відкрили цифровий простір і підвищили доступність фінансових послуг для значної кількості клієнтів. В свою чергу, це відкрило широкі можливості скорочення обігу готівкових грошей, створення рівних умов i прозорості фінансової діяльності для всіх економічних агентів. Окрім цього, зумовило появу цифрових активів, першим типом яких стала криптовалюта, що в свою чергу, відкрило новий етап для розробки амбіційної політики майбутнього розвитку грошей. Таким чином, альтернативні валюти сьогодні представляють неформальну грошову систему, що не перебуває під контролем традиційних інститутів. Їх множина i поширення сформували таке поняття як грошовий плюралізм.

Аналізуючи ставлення суспільства до альтернативних валют, за поведінковим підходом можна виокремити нефінансові і фінансові чинники прийняття альтернативних валют. До перших відносяться можливість купівлі ексклюзивних товарів, дотримання і виконання договірних умов, вплив політичних або моральних стимулів розвитку громад, задоволення бажання і готовність до ризику, зло- чинні наміри щодо отримання нелегального доходу або багатства, ухилення від сплати податків тощо. До других варто включити отримання прибутку від фінансових спекуляцій, використання на свою користь цінову різницю при біржовій торгівлі, зміну вартості внаслідок інфляції, зміну обмінного курсу, прагнення до заощадження грошей тощо.

Поряд 3 розумінням передумов виникнення, подальше поширення альтернативних валют паралельно 3 традиційними грошима не можливе без сприйняття їх сутності. Сьогодні альтернативні валюти, як вже зазначалося раніше, $\epsilon$ доповненням до фіатних грошей національної або міжнародної валютної системи. Шляхи ї створення $\epsilon$ досить різноманітними: від випуску їх національними або місцевими державними органами для підтримки або стимулювання економіки до створення приватними особами або установами. Обіг альтернативних валют частіше обмежений географічною зоною, наприклад, територією певної країни, а представлені вони можуть бути у вигляді конкретного товару або абстрактними розрахунковими одиницями, або без наявності конкретних форм.

Паралельне впровадження альтернативних (приватних) валют за умови визнання їх товаром і випуску ринковим способом, серед яких внаслідок конкуренції активними залишаться такі, що найкращим чином будуть виконувати функції грошей заради досягнення грошової стабільності, обгрунтував ще Ф.А. Хайек [1].

Спираючись на підхід П. Бйоттке до походження грошей, тобто те, що гроші спочатку були неформального походження, а після появи цен- 
тральних банків, прийняття нормативно-правових норм, політик, регулювання тощо, вони стали внутрішнім та/або зовнішнім (світовим) інститутом [2, с.335], сформовано авторську позицію до сутності альтернативних валют. Вважаємо, що альтернативні валюти виникають самостійно, як ендогенний інститут, i розвиваються в процесі самоорганізації, що визначається накопиченням інформації та іiі перетворенням у знання, а також вміння, норми, досвід i практику співпраці вільних людей в умовах постійних змін. 3 формуванням необхідного інституційного середовища вони наближаються до переходу в екзогенний інститут, швидкість і завершеність якого залежить від тривалості правової невизначеності і позиції сприйняття офіційними регуляторами та іншими офіційними фінансовими установами, якщо такі альтернативні валюти не ініційовані безпосередньо ними ж.

Достатньо повно можливість виконувати альтернативними валютами функції грошей обгрунтовано в роботі [3, с.64-66], де доведено, що їм притаманні функції міри вартості, засобу обігу і засобу платежу, нагромадження, світових грошей, а також специфічні функції, які знаходять свою реалізацію або зникають, зокрема, регуляторна, інтегруюча та соціальносегментуюча, а також соціальні - історико-культурологічна, статусна, соціально-стратифікаційна, регуляторно-поведінкова, конфліктогенна, моральності. Формування безготівкового суспільства передбачає виокремлення типів альтернативних валют як матеріальних і цифрових, зокрема: 1) валюти 3 внутрішньою корисністю; 2) токени, що мають меншу внутріш- ню цінність внаслідок обмеженого використання; 3) централізована цифрова валюта; 4) розподілена або децентралізована валюта [4]. Бачимо, що до категорії альтернативних валют включено цифрові валюти, обіг яких вже не обмежується певною географічною зоною, для цього достатньо динамічно i швидко було забезпечено їх конвертованість між різними видами, розроблено криптовалютні гаманці, специфічні системи та платформи для розширення їх функцій i задоволення побажань власників.

До особливостей альтернативних валют можна віднести те, що вони $\epsilon$ : платіжними засобами; мають емітента, відмінного від держави; циркулюють поза банківською системою; здатні виконувати традиційні і специфічні функції грошей. Уточнюючи характеристичні особливості альтернативних валют, зауважимо, що вони, на нашу думку, можуть бути класифіковані за такими ознаками: 1) актив - матеріальний і нематеріальний; 2) територіальне поширення глобальні, регіональні або місцевої спільноти, корпоративні. Так, корпоративна валюта заснована на обміні продуктами i послугами в системі відносин В2В переважно малого і середнього бізнесу, iї не можна обмінювати на законний платіжний засіб, але вона створює додаткові переваги щодо здешевлення кредитів i транзакцій порівняно 3 традиційною валютою; 3) рівень управління (емісія) - централізовані та децентралізовані; 4) ефект дії - економічно і соціально орієнтовані; 5) регулювання - регульовані та нерегульовані; 6) забезпечення - забезпечені i незабезпечені. Варто зазначити, що така типологізація не $є$ остаточною внаслідок 
невпинного розвитку технологій та схем поширення та впровадження альтернативних валют у грошовокредитну систему.

Зараз існує достатньо велика множина альтернативних валют, які виникають в рамках певних концепцій, що претендують на існування паралельно 3 традиційною грошовою системою, проте на нашу думку, найбільш перспективними видами альтернативних валют $\epsilon$ валюти, забезпечені енергією, цифрові валюти та валюти, засновані на часі.

Ідея енерговалюти («енергетичного» долару) та енерговалютної, замість золотовалютної, системи була висловлена ще Т. Едісоном і набула поширення у 90-х роках у працях П. Кузнєцова, який в 1995 році звернувся до ООН з проханням розглянути метод об'єктивної оцінки ефективності через енергетичні показники, можливість створення Міжнародного Центру енергетичних розрахунків для організації обміну товарною продукцією, не прибігаючи до послуг зграї фальшивомонетників (Міжнародного валютного фонду та банківських систем країн-сімки) [5]. Пізніше вченим було запропоновано навіть змінити номінал світової валюти в грамах золота на номінал в якійнебудь одній $з$ енергетичних одиниць (калоріях, джоулях або кВТ-годинах) [6]. Не дивлячись на те, що концепція енерговалюти не набула широкого поширення та розроблення, відповідно до позицій А. Гальчинського [7], Б. Івасіва [8], О. Лаврушіна [9] та інших учених, енерговалюта відповідає та здатна виконувати функції сучасних грошей.
Цифрові валюти наразі стали невід'ємною ознакою сучасного фінансового світу, після запуску у 2009 році криптовалютної системи. Наразі відбувається активна дискусія щодо сутності, можливостей та загроз криптовалют. До головних загроз та ризиків криптовалют відносять іiі фізичну не підкріпленість та іï використання для розвитку ринку нелегальних товарів (наркотиків, зброї, контрабанди). В той же час до головних переваг криптовалюти відносять практично безмежні можливості і захищеність транзакцій, анонімність, заздалегідь відомий обсяг емісії, відсутність або низька вартість комісій за здійснення платежів. Проте стурбованість центральних банків та інших центральних органів управління пов'язана перш за все 3 iï децентралізованістю, а саме незалежністю емісії за рахунок математичного алгоритму, що може вплинути на монополію емісії грошей і контроль грошових коштів. До інших загроз можна віднести проблему довіри, схожість 3 фінансовою пірамідою, обмеженість розрахунків [10].

Для кращого розуміння особливостей функціонування традиційних, електронних i цифрових валют здійснено компаративний аналіз (табл.1).

Активне поширення криптовалют зумовило появу інших цифрових активів та їх класифікацію, зокрема, за ознаками: рівня захисту та анонімності транзакцій; рівня капіталізації мети використання, ринку обігу, виду емісії $[12,13,14]$. 
Таблиця 1

Компаративний аналіз особливостей традиційних і електронних грошей, цифрової валюти

\begin{tabular}{|c|c|c|c|}
\hline $\begin{array}{l}\text { Характерна } \\
\text { ознака }\end{array}$ & $\begin{array}{l}\text { Традиційні } \\
\text { гроші }\end{array}$ & Електронні гроші & Цифрова валюта \\
\hline Формат грошей & Паперовий & Цифровий & Цифровий \\
\hline $\begin{array}{l}\text { Одиниця } \\
\text { обліку }\end{array}$ & \multicolumn{2}{|c|}{$\begin{array}{l}\text { Традиційна валюта (євро, долар США, } \\
\text { фунт стерлінгів, інші), що має законний } \\
\text { статус пропозиції }\end{array}$} & $\begin{array}{l}\text { Розроблена валюта без } \\
\text { законного статусу пропо- } \\
\text { зиції }\end{array}$ \\
\hline $\begin{array}{l}\text { Правовий ста- } \\
\text { тус }\end{array}$ & Мають & Мають & Не мають \\
\hline Емітент & $\begin{array}{l}\text { Центральний } \\
\text { банк }\end{array}$ & $\begin{array}{l}\text { Законно визначена } \\
\text { установа, що } є \text { емітен- } \\
\text { том електронних гро- } \\
\text { шей }\end{array}$ & \begin{tabular}{l}
\multicolumn{1}{l}{ Приватна компанія або } \\
приватна особа, що діють у \\
межах власних рішень і \\
суджень
\end{tabular} \\
\hline $\begin{array}{l}\text { Вимога наяв- } \\
\text { ності емітента }\end{array}$ & Так & Так & $\mathrm{Hi}$ \\
\hline Порядок емісії & Монопольний & Централізований & Децентралізований \\
\hline $\begin{array}{l}\text { Технічні пере- } \\
\text { думови емісії }\end{array}$ & Немає & Немає & $\begin{array}{l}\text { Безпосередньо залежить } \\
\text { від потужностей } \\
\text { комп’ютерів }\end{array}$ \\
\hline Джерело емісії & Громадське & Приватне & Приватне \\
\hline Обсяг емісії & Гнучкий & Відносно гнучкий & Негнучкий \\
\hline Правила емісії & $\begin{array}{l}\text { Емісія на ос- } \\
\text { нові інфляційно- } \\
\text { го таргетування }\end{array}$ & $\begin{array}{c}\text { Емісія на основі } \\
\text { еквівалентного обміну } \\
\text { на інші грошові форми } \\
\end{array}$ & $\begin{array}{l}\text { Комп’ютерний протокол } \\
\text { з лімітами }\end{array}$ \\
\hline $\begin{array}{l}\text { Зміна умов } \\
\text { емісії }\end{array}$ & Так & Так & $\begin{array}{l}\text { Так, за умови домовле- } \\
\text { ності з основними майне- } \\
\text { рами }\end{array}$ \\
\hline Вартість емісії & Низька & Низька & $\begin{array}{l}\text { Висока внаслідок вит- } \\
\text { рат на електроенергію для } \\
\text { обчислень }\end{array}$ \\
\hline $\begin{array}{l}\text { Пропозиція } \\
\text { грошей }\end{array}$ & Фіксована & Фіксована & Не фіксована \\
\hline Засіб обміну & Так & Так (обмежене) & $\begin{array}{l}\text { Обмежене, зростає в ме- } \\
\text { режевому середовищі }\end{array}$ \\
\hline $\begin{array}{l}\text { Офіційне } \\
\text { визнання як засо- } \\
\text { бу платежу }\end{array}$ & Так & Так & $\mathrm{Hi}$ \\
\hline $\begin{array}{l}\text { Регулювання та } \\
\text { нагляд }\end{array}$ & Здійснюється & Здійснюється & Не здійснюється \\
\hline
\end{tabular}

Джерело: побудовано на основі опрацювання $[3,11,13]$

Ідея альтернативної валюти, заснованої на часі, та валюти громад не $\epsilon$ новою. Вона належить Е. Кану і виникла у відповідь на припинення фінансування американських програм соціального забезпечення для вразливих категорій людей. Е. Кан створив
TimeBanks USA - платформу для навчання людей моделі «рау it forward» [15]. Альтернативна валюта, заснована на часі, - це тип грошей, вартість яких заснована на одиницях часу, коли робочий час можна скоротити до стандартизованої одиниці економічної 
вартості, яку потім можна обміняти. Вона відноситься до регіональних валют.

Інституційна структура впровадження і поширення цієї альтернативної валюти базується на створенні системи обміну (LETS) і тайм-банку (TimeBanking) - спільнот, що працює 3 часом як 3 валютою. TimeBanking створює гроші за допомогою вбудованої щедрості, стимулює творчість, породжує соціальне підприємництво та громадянську активність. Години TimeBank унікальні, бо вони відкидають ринкову ціну, порівнюючи всі години і створюючи тільки моральні зобов'язання [16]. Вони все більше переходять в онлайн. Обмеженням $\epsilon$ конвертація в грошовий вираз і використання поза спільнотою.
Значна кількість TimeBanking працюе в США, Великобританії, Швеції, Японії, Аргентині, Іспанії, Ізраїлі, Греції та інших країнах. Основною метою тайм-банків $\epsilon$ реабілітація неповнолітніх правопорушників, осіб з обмеженими можливостями, підтримка ініціатив захисту прав жінок, створення умов для осіб поважного віку, тобто ії відмінністю $є$ соціальна орієнтованість і толерантність в умовах формування цифрового покоління [17].

Для кращого розуміння вищеозначених видів альтернативних валют доречно здійснити аналіз їх слабких і сильних сторін, загроз і можливостей (табл. 2).

Таблиця 2

SWOT-аналіз сучасних концепцій альтернативних валют

\begin{tabular}{|c|c|c|c|c|}
\hline Валюта & $\begin{array}{l}\text { Слабкі сторо- } \\
\text { ни }\end{array}$ & $\begin{array}{c}\text { Сильні сторо- } \\
\text { ни }\end{array}$ & Загрози & Можливості \\
\hline \multirow{4}{*}{$\begin{array}{l}\text { Цифрові } \\
\text { валюти }\end{array}$} & $\begin{array}{l}\text { цінність зале- } \\
\text { жить від попиту }\end{array}$ & \begin{tabular}{l}
\multicolumn{2}{c}{ здійснення } \\
тран-закцій поза \\
БС
\end{tabular} & \multirow[t]{4}{*}{\begin{tabular}{l}
\multicolumn{2}{c}{ обмежувальне } \\
регулювання i \\
нагляд
\end{tabular}} & $\begin{array}{l}\text { інтенсивне ство- } \\
\text { рення нових валют }\end{array}$ \\
\hline & $\begin{array}{l}\text { використання } \\
\text { обмежене }\end{array}$ & $\begin{array}{l}\text { міжнародний } \\
\text { обмін }\end{array}$ & & \begin{tabular}{l}
\multicolumn{3}{c}{ формування ново- } \\
го онлайн това-
\end{tabular} \\
\hline & $\begin{array}{l}\text { вразливість до } \\
\text { шахрайства }\end{array}$ & $\begin{array}{l}\text { конвертація } \\
\text { iнші валюти }\end{array}$ & & риства \\
\hline & $\begin{array}{r}\text { висока } \\
\text { тильність }\end{array}$ & $\begin{array}{c}\text { крипто- } \\
\text { графічний захист }\end{array}$ & & $\begin{array}{l}\text { розвиток інфра- } \\
\text { структури }\end{array}$ \\
\hline \multirow{3}{*}{$\begin{array}{l}\text { Валюта } \\
\text { громад }\end{array}$} & $\begin{array}{l}\text { використання } \\
\text { на купівлю то- } \\
\text { варів і послуг в } \\
\text { межах громади }\end{array}$ & $\begin{aligned} \text { високий } & \text { рівень } \\
\text { прийняття } & \end{aligned}$ & \multirow[t]{3}{*}{\begin{tabular}{l}
\multicolumn{2}{c}{ внаслідок від- } \\
сутності широко- \\
го поширення \\
може перетвори- \\
тись у ваучерну \\
систему
\end{tabular}} & $\begin{array}{l}\text { забезпечення } \\
\text { стабільності, свобо- } \\
\text { ди від спекуляції і } \\
\text { макроекономічних } \\
\text { факторів }\end{array}$ \\
\hline & \begin{tabular}{l}
\multicolumn{2}{c}{ необхідність } \\
конвертації поза \\
межами громади
\end{tabular} & $\begin{array}{l}\text { підтримується i } \\
\text { може бути обміне- } \\
\text { на на фіатну валю- } \\
\text { ту }\end{array}$ & & $\begin{array}{l}\text { стимулювання } \\
\text { регіонального ро- } \\
\text { звитку }\end{array}$ \\
\hline & \begin{tabular}{l}
\multicolumn{1}{c}{ продаж зале- } \\
жить від попиту в \\
межах громади
\end{tabular} & $\begin{array}{l}\text { здійснення пря- } \\
\text { мих транзакцій без } \\
\text { посередників }\end{array}$ & & $\begin{array}{r}\text { попередження } \\
\text { відтоку капіталу }\end{array}$ \\
\hline $\begin{array}{c}\text { Валюта, } \\
\text { заснована } \\
\text { на часі }\end{array}$ & $\begin{array}{l}\text { неготовність } \\
\text { суспільства }\end{array}$ & $\begin{array}{l}\text { прямий і самий } \\
\text { справедливий об- } \\
\text { мін послугами }\end{array}$ & $\begin{array}{l}\text { нормативне } \\
\text { регулювання, } \\
\text { податки і обме- }\end{array}$ & $\begin{array}{l}\text { відхиляє } \\
\text { хідність уеоб- } \\
\text { будь якої форми }\end{array}$ \\
\hline
\end{tabular}




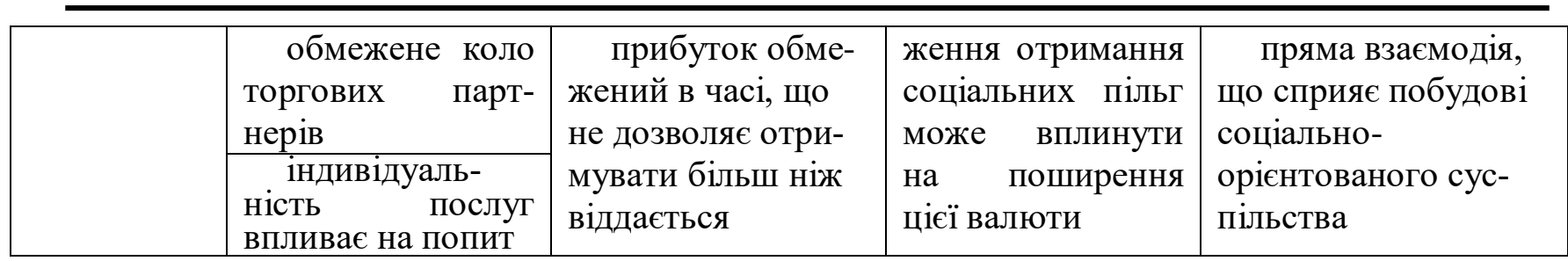

Джерело: власна розробка

Висновки. Сучасний етап розвитку грошового плюралізму можна охарактеризувати наближенням до субсидіарності, основоположному принципу Свропейського Союзу, що полягає у використанні влади і вжитті заходів на будь якому рівні лише в тому випадку і в тій мірі, що є необхідними для суспільного блага. Тому грошовий плюралізм не варто розглядати з позиції конкуренції альтернативних валют до традиційних, адже субсидіарність наголошує на доцільності доповненості сучасної реальності. В цьому аспекті розвиток і поширення альтернативних валют $\epsilon$ найкращим підтвердженням. Напрямами подальшого наукового пошуку передбачається дослідження альтернативних валют в умовах COVID-19, а також впровадження цифрових валют центральних банків у відповідь кредитнобанківської системи на розвиток грошового

\section{Список використаної літератури}
1. Хайек
$\Phi$.
A.
Частные
деньги.
URL: https://www.litmir.me/br/?b=139813\&p=2 (дата звернення: 18.04.2021)

2. Boettke P.J., Coyne Ch.J., Leeson P.T.Institutional Stickiness and the New Development Economics. American Journal of Economics and Sociology. 2008. Vol. 67, no. 2. P. 331-358.

3. Пантєлєєва Н.М. Реформування міжнародної валютної системи в умовах формування нової фінансової архітектури. Фінансовий простір. 2011. № 3. C. $28-42$.

4. Hileman G. A History of Alternative Currencies. URL: https://www.hillsdale.edu/wp-content/uploads/2016/02/FMF-2014-A-History-ofAlternative-Currencies.pdf (дата звернення: 18.04.2021)

5. Кузнецов П.Г. Меморандум в ОOH. URL: http://www.pobiskmemory.narod.ru/files/memorandum.zip (дата звернення: 18.04.2021)

6. «Динар залива», золото, энерговалюта и вектора в мультивалютное будущее после Первой глобальной Великой депрессии. URL: http://elitetrader.ru/index.php?newsid=5932 (дата звернення: 18.04.2021)

7. Гальчинський А. Теорія грошей. К. : Видавництво Соломії Павличко «Основи», 2001. 416 с. 
8. Івасів Б.С. Гроші та кредит: Підручник. Вид. 3-тє, змін, й доп. Тернопіль: Карт-бланш, К.:Кондор, 2008. 528 с.

9. Деньги, кредит, банки : учебник / кол. авторов ; под ред. д-ра экон. наук, проф. О.И. Лаврушина. 9-е изд., стер. М.: КНОРУС, 2010. 560 с.

10. Суворкова Н.М. Проблемы, препятствующие развитию цифровых криптографических валют в России. Аллея науки. 2018. Т.4, №9 (25). С. 65-68. URL: https://www.elibrary.ru/item.asp?id=36542675(дата звернення: 18.04.2021)

11. Шлюндт Н. Ю. Национальная цифровая валюта как контрсанкционный инструмент (на примере современных американовенесуэльских отношений). Ars Administrandi (Искусство управления). 2018. T.10, № 3. C. 519-530. doi: 10.17072/2218-9173-2018-3-519-530.

12. Кочергин Д.А., Янгирова А.И. Центробанковские цифровые валюты: ключевые характеристики и направления влияния на денежнокредитную и платежную системы. Финансы: теория и практика. 2019. №23(4). C. 80-98. doi: https://doi.org/10.26794/2587-5671-2019-23-4-80-98

13. Юзефальчик И. Цифровые валюты центральных банков: подходы к внедрению и роль в финансовой системе. Банковский вестник. 2019. №11 (676). C. 27-34. URL: https://www.elibrary.ru/item.asp?id=41583386 (дата звернення: 18.04.2021)

14. Пантєлєєва Н.М., Рогова Н.В. Криптоактиви: проблеми типізації та регулювання. Регулювання та перспективи ринку криптоактивів: матеріали Всеукраїнського наукового форуму, 23 жовтня 2018. КНЕУ, м. Київ. С.138-141.

15. Timebanking, the alternative currency that could change our society URL: https://www.fairplanet.org/story/timebanking-the-alternative-currency-thatcould-change-our-society/ (дата звернення: 18.04.2021)

16. TimeBank Hours: A Time-Based Currency For Communities That Care. URL: https://www.changemakers.com/strongcommunities/entries/timebank-hourstime-based-currency-communities-care (дата звернення: 18.04.2021)

17. Forget Bitcoins, time to shift on Time-Based Currency. URL: https://medium.com/socialtech-e-v/forget-bitcoins-time-to-shift-on-time-basedcurrency-b8dc66719592 (дата звернення: 18.04.2021) 